\title{
Front Matter: Volume 11497
}

, "Front Matter: Volume 11497," Proc. SPIE 11497, Ultrafast Nonlinear Imaging and Spectroscopy VIII, 1149701 (29 September 2020); doi: $10.1117 / 12.2581635$

SPIE. Event: SPIE Optical Engineering + Applications, 2020, Online Only 


\title{
PROCEEDINGS OF SPIE
}

\section{Ultrafast Nonlinear Imaging and Spectroscopy VIII}

\author{
Zhiwen Liu \\ Demetri Psaltis \\ Kebin Shi \\ Editors
}

24 August - 4 September 2020

Online Only, United States

Sponsored and Published by

SPIE 
The papers in this volume were part of the technical conference cited on the cover and title page. Papers were selected and subject to review by the editors and conference program committee. Some conference presentations may not be available for publication. Additional papers and presentation recordings may be available online in the SPIE Digital Library at SPIEDigitalLibrary.org.

The papers reflect the work and thoughts of the authors and are published herein as submitted. The publisher is not responsible for the validity of the information or for any outcomes resulting from reliance thereon.

Please use the following format to cite material from these proceedings:

Author(s), "Title of Paper," in Ultrafast Nonlinear Imaging and Spectroscopy VIII, edited by Zhiwen Liu, Demetri Psaltis, Kebin Shi, Proceedings of SPIE Vol. 11497 (SPIE, Bellingham, WA, 2020) Seven-digit Article CID Number.

ISSN: 0277-786X

ISSN: 1996-756X (electronic)

ISBN: 9781510638006

ISBN: 9781510638013 (electronic)

Published by

SPIE

P.O. Box 10, Bellingham, Washington 98227-0010 USA

Telephone +1 3606763290 (Pacific Time) · Fax +1 3606471445

SPIE.org

Copyright (c) 2020, Society of Photo-Optical Instrumentation Engineers.

Copying of material in this book for internal or personal use, or for the internal or personal use of specific clients, beyond the fair use provisions granted by the U.S. Copyright Law is authorized by SPIE subject to payment of copying fees. The Transactional Reporting Service base fee for this volume is $\$ 21.00$ per article (or portion thereof), which should be paid directly to the Copyright Clearance Center (CCC), 222 Rosewood Drive, Danvers, MA 01923. Payment may also be made electronically through CCC Online at copyright.com. Other copying for republication, resale, advertising or promotion, or any form of systematic or multiple reproduction of any material in this book is prohibited except with permission in writing from the publisher. The CCC fee code is $0277-$ $786 \times / 20 / \$ 21.00$.

Printed in the United States of America by Curran Associates, Inc., under license from SPIE.

Publication of record for individual papers is online in the SPIE Digital Library.

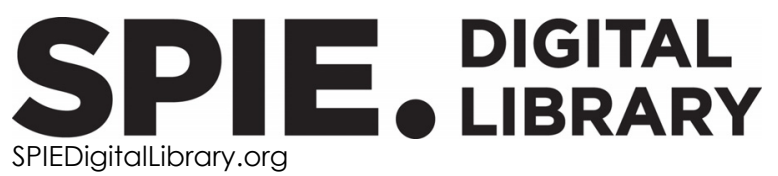

Paper Numbering: Proceedings of SPIE follow an e-First publication model. A unique citation identifier (CID) number is assigned to each article at the time of publication. Utilization of CIDs allows articles to be fully citable as soon as they are published online, and connects the same identifier to all online and print versions of the publication. SPIE uses a seven-digit CID article numbering system structured as follows:

- The first five digits correspond to the SPIE volume number.

- The last two digits indicate publication order within the volume using a Base 36 numbering system employing both numerals and letters. These two-number sets start with $00,01,02,03,04$, 05, 06, 07, 08, 09, 0A, OB ... 0Z, followed by 10-1Z, 20-2Z, etc. The CID Number appears on each page of the manuscript. 


\section{Contents}

ULTRAFAST NANOSCALE IMAGING AND SPECTROSCOPY II

11497 OC Low-frequency stimulated Raman spectroscopy measurements at electrochemical interfaces [11497-11]

ULTRAFAST SOURCES AND APPLICATIONS

11497 OF Multi-dimensional spectroscopy with cascade four-wave mixing in the extreme ultraviolet [11497-14]

ULTRAFAST ELECTRON DIFFRACTION AND IMAGING

$114970 \mathrm{~J} \quad$ Ultrafast structural dynamics of materials captured by relativistic electron bunches (Invited Paper) [11497-18]

BIOLOGICAL APPLICATIONS

11497 OT Comparative studies of the fluorescence spectroscopy and dynamics of mCerulean3 and mTurquoise2.1 as donors in FRET pairing with mCitrine (Invited Paper) [1 1497-27]

ADVANCED IMAGING TECHNOLOGIES I

11497 OV Ultrafast super-resolution imaging via auto-correlation two-step deconvolution (Invited Paper) [11497-29]

11497 OW Nonlinear photo-response in upconversion nanoparticles for in-depth super-resolution imaging (Invited Paper) [11497-30]

POSTER SESSION

1149713 Ultrafast polarization-modulation transient spectroscopy to study electronic excited state dynamics in biological molecules [11497-37]

1149714 Anisotropic decay of polarized fluorescence of FAD in water-methanol solutions [1 1497-38] 
1149716 Lubricating oil degradation analysis due to temperature through Raman spectroscopy [11497-40]

1149717 All-fiber pulsed laser source based on Raman dissipative soliton generation for biological tissue analysis [11497-41] 